\title{
FEATURE Slurry trenches and relief wells installed to strengthen Ohio and Mississippi river levee systems
}

Kenneth R. Olson and Lois Wright Morton

n April of 2011, the Ohio River began flooding farmland and cities in Ohio, Indiana, Kentucky, and Illinois, which were not protected by levees. Cairo, Illinois, and many of the other cities on the Ohio and Mississippi rivers protected by levees did not flood, but their levees and floodwalls were in danger of failing due to the constant water pressure against and under the levees and floodwalls. The extra weight of the river at flood stage pushes water underneath levees and floodwalls increasing the potential for sand boils and undermining the strength of the levee and its capacity to hold back floodwater (Camillo 2012; Morton and Olson 2015). By early May of 2011, the Ohio River gage at Cairo, Illinois, had reached $18.7 \mathrm{~m}(61.7 \mathrm{ft}$ ) (NOAA 2012), and floodwaters were starting to put significant pressure on both Ohio and Mississippi river levee and floodwall systems to the north of Cairo (figure 1). Although, the New Madrid Floodway south of the Ohio and Mississippi river confluence at Cairo was deliberately breached on May 2, 2011, by the United States Army Corps Engineers (USACE) to reduce levee pressure, the levee system north of Cairo, the levee system south of Hickman, Kentucky, and the Ohio River levee near Mound City, Illinois, were considerably weakened and in need of repair and strengthening to withstand future river pressure (Olson and Morton 2012).

\section{HISTORIC GEOLOGICAL FEATURES OF THE CACHE RIVER VALLEY AREA}

The Alexander County area north of Cairo was the location during the Woodfordian period $(30,000$ years $\mathrm{BP})$ where the floodwaters from the ancient Ohio River Watershed drained through the Cache

Kenneth R. Olson is professor of soil science in the College of Agricultural, Consumer, and Environmental Sciences, University of Illinois, Urbana, Illinois, and Lois Wright Morton is professor of sociology in the College of Agriculture and Life Sciences, lowa State University, Ames, lowa.

\section{Figure 1}

Map of the Ohio, Mississippi, and Cache river levees north of Cairo, Illinois, and south of the Cache River. Map by Mic Greenberg.

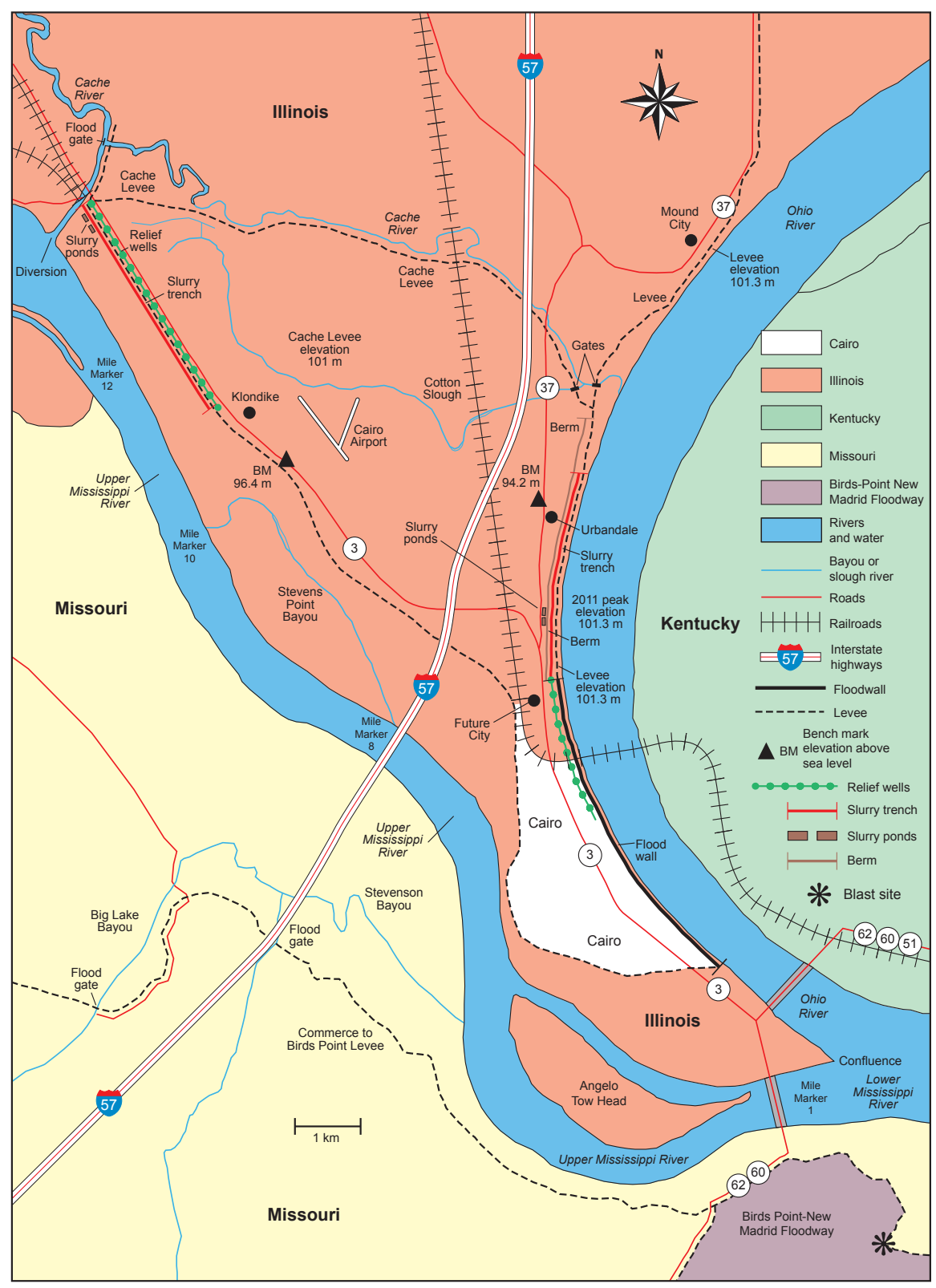

RiverValley and converged with the ancient Mississippi River Watershed waters just west of the Horseshoe Lake Conservation Area (Olson and Morton 2013a, 2013b, 2014a). The Cache RiverValley is 5 to $8 \mathrm{~km}$
( 3 to $5 \mathrm{mi}$ ) wide as a result of the previous river having been much larger when it carried waters from the ancient Ohio River Valley in addition to the local waters from the Cache River (figure 1). 


\section{POTENTIAL CONSEQUENCES OF AN OHIO, MISSISSIPPI, OR CACHE RIVER LEVEE FAILURE}

The system of levees north of Cairo and south of Cache River levee (figure 1) on the Mississippi, Ohio, and Cache rivers protect three towns, the Cairo airport, and Illinois farmland (Olson and Morton 2013a, 2013b). Failure of any one of these levees would cause severe flooding of Urbandale, Klondike, and Future City, Illinois, and the surrounding 800 ha $(2,000 \mathrm{ac})$ of agricultural lands, and cause the Cairo floodgate between raised railroad beds over Route 3 to be closed. This north of Cairo area includes 1,214 ha $(3,000 \mathrm{ac})$ of levee-protected land (figure 2) with silty soils, (Tice silty clay loam, Riley silty clay loam, Darwin silty clay loam, and Cape and Karnak silty clay loam) (Parks and Fehrenbacher 1968) and is at a slightly higher elevation than the City of Cairo. Flooding would have caused significant loss of life and severe damage to buildings in the areas to the north of the City of Cairo. A levee breach could damage a hundred or more buildings in the Future City, Klondike, and Urbandale areas and require the local population to be evacuated.

The area north of Cairo has the potential capacity to store up to 3 to $4.6 \mathrm{~m}$ (10 to $15 \mathrm{ft}$ ) depth of floodwater on 1,214 ha $(3,000 \mathrm{ac})$ of the 3,804 to 5,556 ha-m $(30,000$ to 45,000 ac-ft) (Olson and Morton 2012). This amount of temporary floodwater storage would have done little to drop record flooding levels on the Ohio and Mississippi rivers (probably less than $25 \mathrm{~cm}$ [10 in] for several hours) and would have had even less effect in the Lower Mississippi River between Cairo, Illinois, and New Orleans, Louisiana. The breaching of Ohio, Mississippi, or Cache levees and flooding of the area north of Cairo would also have blocked the planned evacuation route (Route 3 ) used by Cairo citizens on May 1, 2011.

\section{RESTORATION AND STRENGTHENING OF OHIO, MISSISSIPPI, AND CACHE RIVER LEVEES NORTH OF CAIRO}

Following the flood of 2011, USACE allocated US\$6 million to address the Mississippi River levee seepage in the levee north of Cairo, with work starting in October of 2011. A total of 28 relief

\section{Figure 2}

The leveed diversion which redirects the middle Cache River water into the Mississippi River and blocks it from draining into the Ohio River via the lower Cache River.

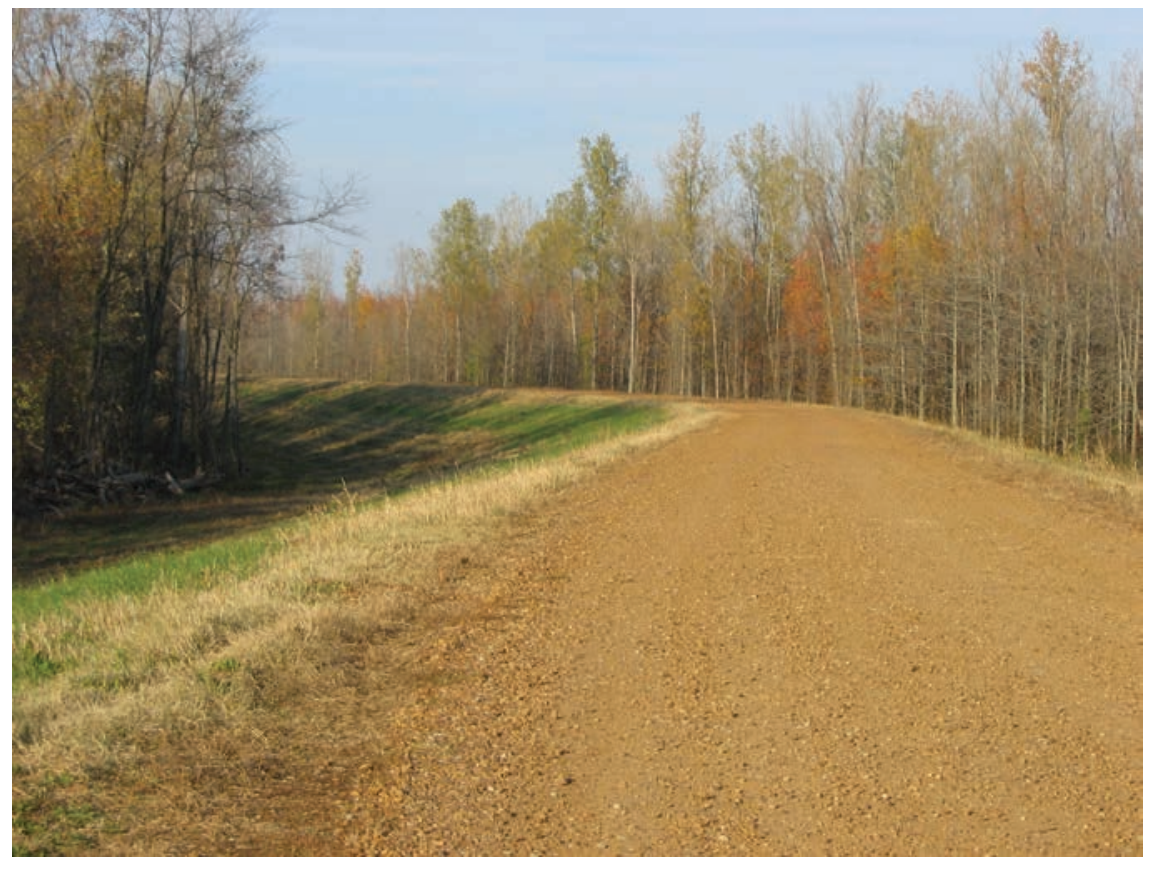

\section{Figure 3}

One of the 28 relief wells located between the Mississippi River levee and Route 3 just northeast of Cairo county airport.

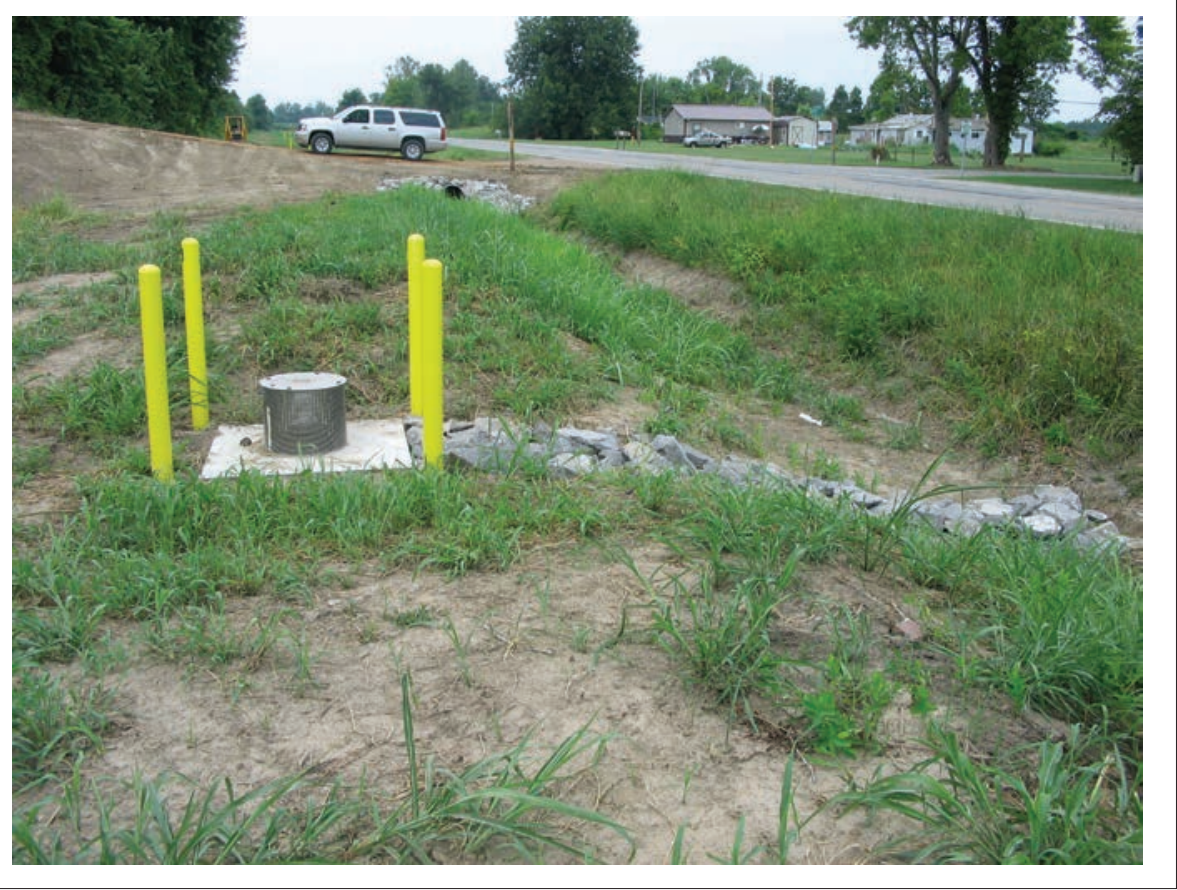

wells, which drain into a Route 3 road ditch (figure 3), were constructed northeast of the Cairo airport and south of the Cache River levee. The relief wells were built to reduce damaging uplift pressure from excessive seepage through pervious materials that were insufficient to block water flow under the levee (Veeesaert 


\section{Figure 4}

Diagram illustrating the landscape relationship of the Mississippi River, the slurry trench, the levee, relief wells, ditches, and Route 3 north of Cairo. Diagram by Mic Greenberg.

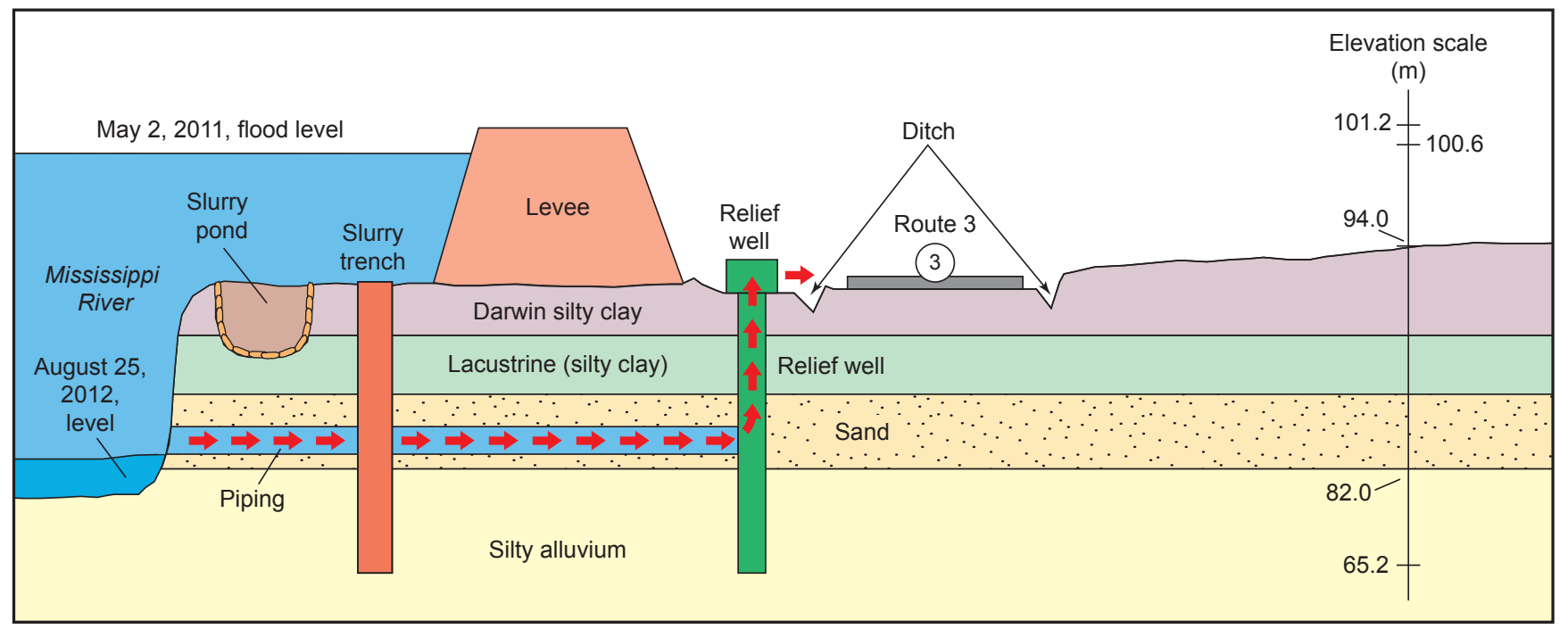

1990). Relief wells control the pressure and are designed to help prevent piping of sediments, which is the real threat to levees and floodwalls (Morton and Olson 2015; Camillo 2012). These wells are designed to control the direction and quantity of seepage and together form a collection system to discharge water back into the Mississippi River (figure 4). Slurry trenches, typically 0.6 to $1.2 \mathrm{~m}$ (2 to $4 \mathrm{ft}$ ) wide and between 16 and $29 \mathrm{~m}$ (35 to $95 \mathrm{ft}$ ) deep are used to create an impervious barrier that cuts off the seepage flow and potential piping of sediment by water (Nemati 2007). They consist of Bentonite or drilling mud clays that are usually formed from volcanic mineral (Montmorillonite) clays and are available in powdered form which when added to water form a thick, sticky viscous fluid (Nemati 2007). The hydration of the clay particles causes them to bond and swell, forming a gel that can be poured into the slurry trench. Bentonite bags were brought in and mixed in slurry ponds (figure 5 ) for injection into $2,180 \mathrm{~m}(7,200 \mathrm{ft})$ of slurry trenches (figure 6) in an effort to reinforce the well and restrict the underground flow of water under the levee. The work on the Mississippi River slurry trenches was completed in November of 2012.

In June of 2012, the US Army Corps of Engineers (USACE) received US $\$ 802$

\section{Figure 5}

Two slurry ponds where the Bentonite bags were dumped and mixed with water to create slurry for the trench.

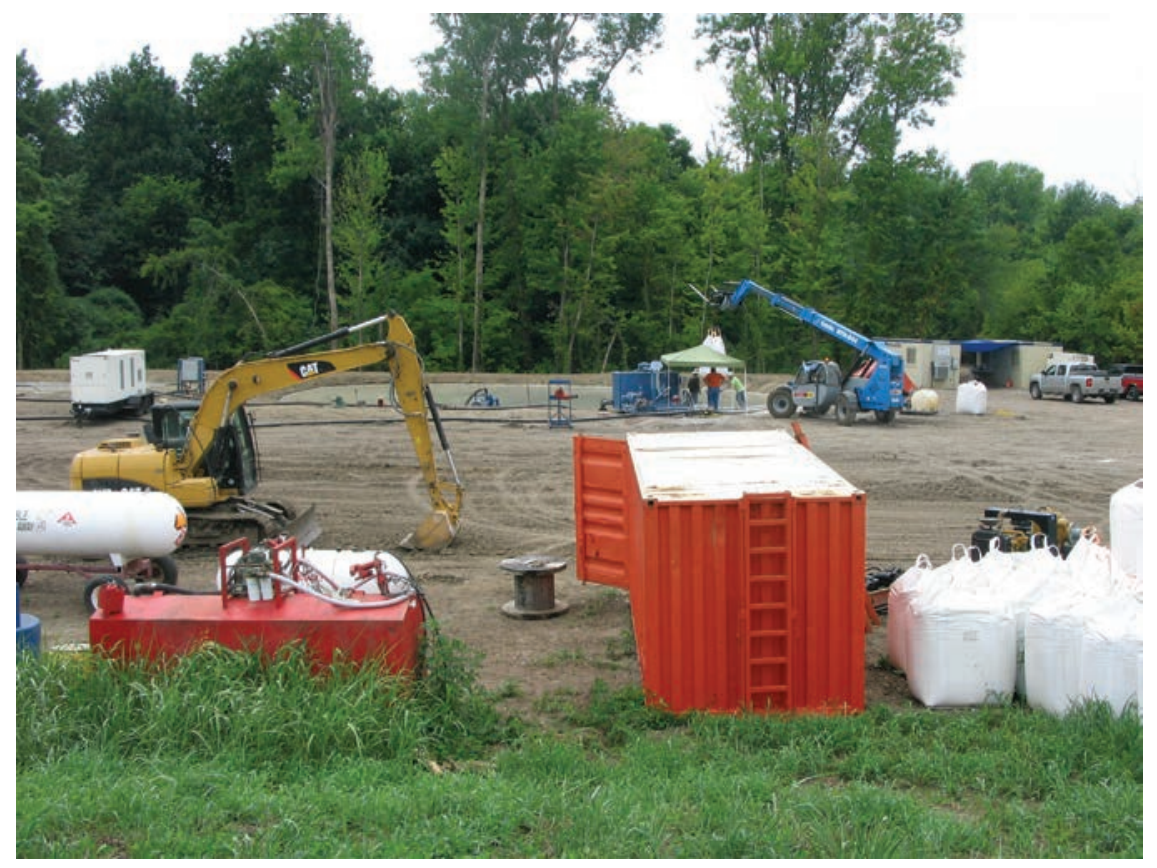

million in emergency Mississippi River flood-repair funding for up to 143 high priority projects to address levee repairs, reconstruct river channels, and repair other flood-control projects in response to the spring of 2011 flood, which set records from Cairo, Illinois, to the Gulf of Mexico.
Both the New Madrid Floodway repair and the Cairo restoration project were high on the list with the USACE targeting US\$46 million to repair the damage to the Cairo area flood-control system north of the confluence of the Ohio and Mississippi rivers. 


\section{Figure 6}

Slurry trench between the levee and Mississippi River.

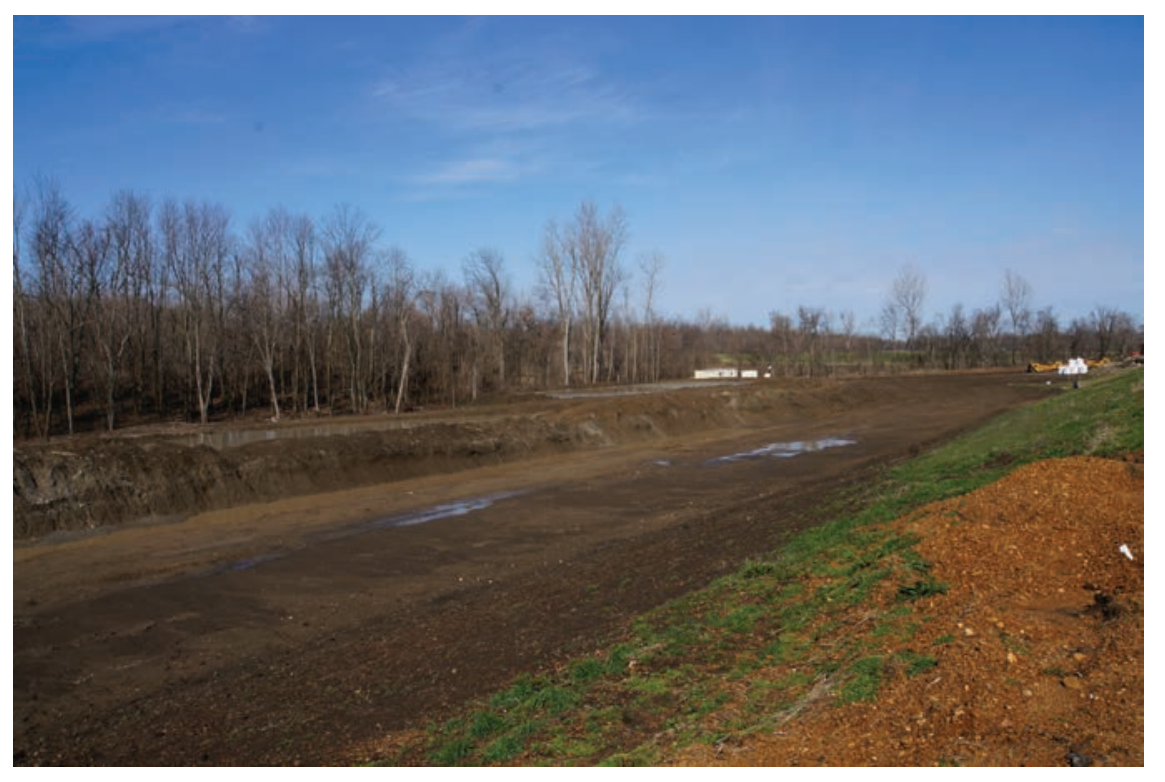

Approximately US $\$ 20$ million additional dollars were used to complete the restoration of the Mississippi River levee north of Cairo with repairs, including the finishing of the 2,182 $\mathrm{m}(7,200 \mathrm{ft})$ slurry trench and 28 relief wells (figures 1, 3, and 4) project that was started in the fall of 2011. The USACE has responsibility for managing river flows and navigation during flood and drought conditions. Thus another US\$26 million was used to not only increase protection provided by the Cairo floodwall on the Ohio River side by putting in 31 relief wells adjacent to the Cairo floodwall (figure 1) and to help prevent erosion of the river bank along the Ohio River side of Cairo (Ragan 2012) but also to dredge the Ohio River and Mississippi River channels north of Cairo. The Ohio and Mississippi river channels were dredged in 2012 to maintain a $91 \mathrm{~m}$ (300 ft) wide and $2.7 \mathrm{~m}$ (9 ft) deep shipping channel in dry periods, such as from July of 2012 to February of 2013, when the Ohio River water level dropped below 2.4 m (7.7 ft) (Olson and Morton 2014b). Without a shipping channel of sufficient depth, barges would have to be lightened or held back until seasonal rains and the Ohio and Mississippi river flows are restored to more normal levels. Even in the drought year of 2012, the USACE battled to manage and control the Ohio and Mississippi rivers.
A $1,782 \mathrm{~m}(5,400 \mathrm{ft})$ slurry trench and two berms were added to the Ohio River levee system between Mound City and Cairo north of the Ohio River floodwall (figures 1, 5, and 6) east of Route 37 and south of the Cache River levee. These projects were designed to prevent seepage during future major flooding, and all work was completed by November of 2013. Another project flattened the slope on the Mississippi River levee and widened its crown. Improvements including work on pump stations, drainage systems, and small levees, some of which failed in April of 2011, were completed in the Cache River Valley area north of Cairo. These projects were funded by the county matching funds with the USACE and combinations of grants from the Delta Regional Authority and the state of Illinois (Koenig 2012). North of Cairo and south of the Cache River levee, the smaller towns such as Urbandale, Future City, and Klondike are now better protected from major flooding in the future.

\section{IMPACTS OF FLOODING ON FARMLAND AND TOWNS LOCATED NORTH OF CAIRO AREA}

The Ohio, Mississippi, and Cache river levees held during the 2011 high water period, and thus there was no structural damage in Klondike, Urbandale, and Future City and little flood damage to most of the 1,000 ha $(2,500 \mathrm{ac})$ of agricultural land within the levee-protected area north of Cairo. However, there were approximately $100 \mathrm{ha}(250 \mathrm{ac})$ that experienced some internal flooding from local rains (within the boundaries of the three levees, south of the Cache levee and north of the Cairo airport) that could not drain through the closed Cotton Slough (figure 1) gate on the Cache levee.

Approximately 405 ha $(1,000 \mathrm{ac})$ of agricultural land north of the lower Cache River levee was flooded by the middle Cache River as a result of Mississippi River backing up through the diversion (figure 2) and blocking the westward flow of the middle Cache River. This caused a backup in the middle Cache River, which flooded the adjacent forest covered alluvial soils (e.g., Bonnie silt loam, wet; Piopolis silty clay loam, wet; and Karnak silty clay, wet) and flooded the slightly higher cultivated Petrolia silty clay loam and the Cape and Karnak silt loam soils. These cultivated soils drained by the middle of June of 2011 and were planted to soybeans (Glycine max L.) after the Ohio and Mississippi rivers dropped below flood stage.

\section{IMPACTS OF 2011 FLOODING ON UNLEVEED AGRICULTURAL LANDS AND FORESTED LANDS}

High water levels in the spring of 2011 on the Ohio River caused the Upper Mississippi River near the confluence to back up for many kilometers (miles) to the north of Cairo. Floodwaters backed up into tributaries and through the diversion (figures 1 and 2), which blocked the drainage of local floodwaters from a heavy May rain. The record $18.7 \mathrm{~m}(61.7 \mathrm{ft})$ peak on the Ohio River at Cairo flood gage resulted in approximately $160 \mathrm{ha}(400 \mathrm{ac})$ of alluvial land along the northeast side of the Upper Mississippi River (figure 1) between mile marker 8 and 12 being flooded. Approximately $40 \mathrm{ha}(100 \mathrm{ac})$ had been cultivated, and the other 120 ha (300 ac) remained in forest. Alluvial land consists of recently deposited sediment that varies widely in texture (from clay to sand), and layers are commonly stratified. Detailed deposition, erosion, and channel separa- 
tion of the soils surveyed between 1957 and 1963 was impractical, and thus soil series within the Alluvial Land map unit are not differentiated. The natural vegetation ranges from recent growth of willows and other plants to stands of cottonwood (Populus deltoides L.), sycamore (Plantanus occidentalis L.), and sweet gum (Liquidambar styraciflua L.).

The Upper Mississippi River, which normally is $0.9 \mathrm{~km}(0.5 \mathrm{mi})$ wide, was almost $3 \mathrm{~km}$ ( $2 \mathrm{mi}$ ) wide in places between mile marker 8 and 12 as a result of the backup. The floodwater covered the unleveed bottomlands in both Illinois and Missouri. The bottomland in Missouri between the Upper Mississippi River and the Commerce to Birds Point levee is either in forest or agricultural land with no farmsteads or towns. All bottomlands between the Upper Mississippi River and the levee with an elevation of less than $100.6 \mathrm{~m}$ (332 $\mathrm{ft}$ ) above sea level were flooded. These bottomlands are riparian forest-transition ecosystems with fertile, fine textured clay or loam soils that are enriched by nutrients and sediments deposited during seasonal floods (Anderson and Samargo 2007). The Illinois bottomlands are sources of additional water storage capacity during flooding, and these wet soils help filter pollutants, recharge the water table, and capture sediment before it reaches the main flow of the river (Anderson and Samargo 2007).

There was no significant soil erosion or soil damage revealed after the floodwaters receded from these unleveed bottomlands in late May of 2011. Failed levees are the most common cause of significant land scouring and soil damages in the form of crater lakes, gullies, and sand deltas. During April of 2011, the slow rise in the Ohio and Mississippi rivers gradually covered the 600 ha $(1,500 \mathrm{ac})$ of unleveed farmland with floodwater that eventually reached depths of more than $6.7 \mathrm{~m}(22 \mathrm{ft})$. The floodwater left behind thin silt and clay depositions, which were incorporated into the topsoil layer of the alluvial soils using tillage equipment. The mixing in of sediment into the topsoil seldom results in significant loss of soil productivity.

\section{CONCLUSIONS}

In 2011, the record Ohio River flood resulted in the USACE blasting open the Birds Point,
Missouri, fuse plug levee to protect Cairo and lower Mississippi River cities and lands. However, the record flood level had already put tremendous pressure on and under the Ohio and Mississippi river levees in the area north of Cairo and south of the Cache River levee. After the flooding receded and river levels dropped, seepage problems under the Mississippi and Ohio River levees were treated by creating slurry trenches and installing relief wells. USACE spent US\$26 million to restore the area north of Cairo, including the Ohio, Mississippi, and Cache River levees and the Ohio and Mississippi river shipping channels.

Local floodwater in the lower Cache River Valley, south of the diversion could not flow into the Ohio River since it was blocked by the Cache River levee on the south side and by the closed gate at the Ohio and Cache river levees. As a result, forestland and agricultural lands along the lower Cache River flooded. Weather extremes have resulted in the Ohio River reaching $18.7 \mathrm{~m}(61.7 \mathrm{ft})$ in May of 2011 and dropping to $2.4 \mathrm{~m}(7.7 \mathrm{ft})$ or less in October of 2012, creating substantive challenges for the USACE in their attempts to manage the Ohio and Mississippi rivers and protect cities built on the floodplain, like Cairo, Illinois, and adjacent agricultural lands. The river channel and the systems of levees along these rivers need post-disaster assessment, constant monitoring for structural integrity, and continuous routine and remedial repair to be prepared for future extreme water levels.

\section{ACKNOWLEDGEMENTS}

Funding support comes from Regional Research Project No. 15-372 and in cooperation with NorthCentral Regional Project No. NCERA-3 Soil Survey. Published with funding support from the Director of the Illinois Office of Research, College of Agricultural, Consumer, and Environmental Sciences, University of Illinois, Urbana, Illinois. Additional funding was provided by the USDA National Institute of Food and Agriculture (NIFA) Integrated Water Program agreement 2008-51130-19526, Heartland Regional Water Coordination Initiative, and the Iowa Agriculture and Home Economics Experiment Station, College of Agriculture and Life Sciences, at Iowa State University.

\section{REFERENCES}

Anderson, J., and E. Samargo. 2007. Bottomland Hardwoods. Morgantown, WV: West Virginia University, Division of Forestry and Natural Resources. http://forestandrange.org/new_wetlands/index.htm.

Camillo, C.A. 2012. Divine Providence: The 2011 Flood in Mississippi River and Tributaries Project. Vicksburg, MS: Mississippi River Commission.

Koenig, R. 2012. Corps balancing levee repairs on Missouri, Illinois sides of Mississippi. St. Louis Beacon. July 30, 2012.

Morton,L.W., and K.R. Olson. 2015.Sinkholes and sand boils created during 2011 record flooding in Cairo, Illinois. Journal of Soil and Water Conservation 70(3):49A-54A, doi:10.2489/jswc.70.3.49A.

Nemati, K.M. 2007. Temporary Structures: Slurry Trench/Diaphragm Walls CM420. Seattle, WA: University of Washington, Department of Construction Management.

NOAA (National Oceanic AtmosphereAdministration). 2012. Historic crests. Cairo, IL: National Weather Service, Advanced Hydrologic Prediction Service.

Olson, K.R., and L.W. Morton. 2012. The effects of 2011 Ohio and Mississippi river valley flooding on Cairo, Illinois, area. Journal of Soil and Water Conservation 67(2):42A-46A, doi:10.2489/ jswc.67.2.42A.

Olson, K.R., and L.W. Morton. 2013a. Impacts of the 2011 Len Small levee breach on private and public Illinois lands. Journal of Soil and Water Conservation 68(4):89A-95A, doi:10.2489/jswc.68.4.89A.

Olson, K.R., and L.W. Morton. 2013b. Soil and crop damages as a result of levee breaches on the Ohio and Mississippi rivers. Journal of Earth Sciences and Engineering 3:139-158.

Olson, K.R., and L.W. Morton. 2014a.The 2011 Ohio River Flooding of the Cache RiverValley in southern Illinois. Journal of Soil Water Conservation 69(1):5A-10A, doi:10.2489/jswc.69.1.5A.

Olson, K.R., and L.W. Morton. 2014b. Dredging of the fractured bedrock-lined Mississippi River Channel at Thebes, Illinois. Journal of Soil Water Conservation 69(2):31A-35A, doi:10.2489/jswc.69.2.31A

Parks, W.D., and J.B. Fehrenbacher. 1968. Soil Survey of Pulaski and Alexander counties, Illinois. Washington, DC: USDA Natural Resource Conservation Service.

Ragan, E. 2012. Cairo to fare better in next flood. Southeast Missourian. July 29, 2012.

Veesaert, C.J. 1990. Inspection of Embankment Dams. Session X in Embankment Dams. Bureau of Reclamation. http://www.michigan.gov/ documents/deq/deq-p2ca-embankmentdaminspection_281088_7.pdf. 